\title{
Australia grants license for therapeutic cloning
}

Almost two years ago, the Australian government legalized the technique used to clone embryos. However, until this past September, no firm in the country had received a green light to apply this technique.

That changed on 16 September when ๖ Australia's National Health and Medical Research Council (NHMRC) announced that its embryo research licensing committee had issued three simultaneous three-year licenses to create cloned embryos-not for reproductive purposes but for the derivation of stem cell lines. With the decision, Australia has entered

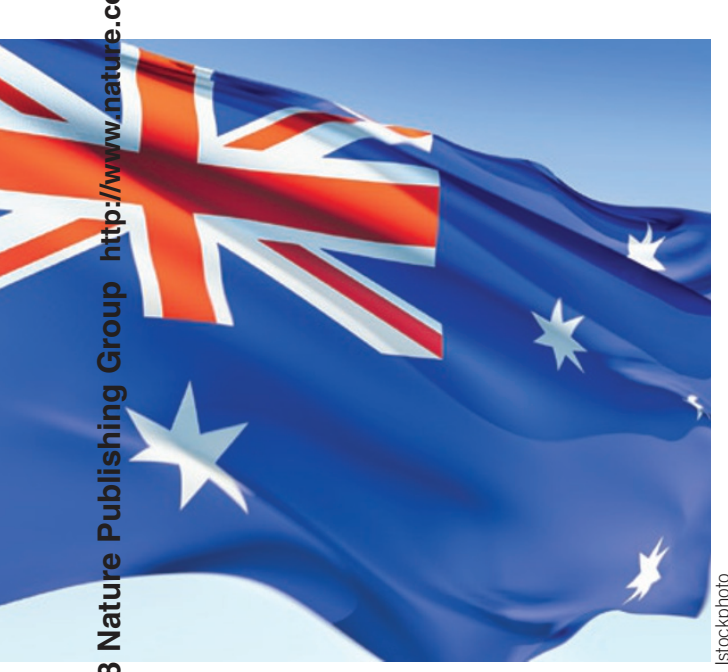

Racing forward: Australian scientists hope to achieve a world first in cloning into the therapeutic cloning race.

Granted to the fertility treatment and research firm Sydney IVF, the licenses apply to cumulus cells, fibroblasts and existing human embryonic stem cell lines. Each license allows researchers to take nuclei from the specified cell type and insert them into up to 2,400 eggs donated for the research and classified as clinically unusable for in vitro fertilization.

The licenses stipulate several special conditions, including a requirement that the scientists record the status of every donated egg, irrespective of whether it is used in the research, and a limit of six embryonic stem cell lines to be created per license.

The licenses stipulate that if the scientists have used 1,600 eggs and have still failed to produce an embryonic stem cell line, no more eggs may be used. Similarly, they cannot continue experimenting on the eggs if they have cloned 160 early-stage 'blastocyst' embryos but have still failed to generate an embryonic stem cell line from these blastocysts.

Researchers have not yet succeeded in deriving viable stem cells from cloned embryos. But Julia Schaft, the stem cell development manager at Sydney IVF, says her team aims to overcome problems that have resulted in poorquality blastocysts. The company's research arm has previously claimed advantages from use of its proprietary culture medium. If Sydney IVF succeeds in creating cloned stem cell lines, it will collaborate with the Australian Stem Cell
Centre (ASCC), a publicly-funded research institution, to prove their viability.

"If they can make human stem cell lines [...], we will be growing them side-by-side with normal human ES lines and human induced pluripotent stem cell lines and comparing them at a genetic, protein and functional level," says Andrew Laslett, a senior scientist at the ASCC, which is being led by an interim board after its board resigned last month.

Schaft says the license applications were submitted in February, and the approval process had been quicker than the company expected: "communications with the NHMRC, the licensing committee and the secretariat have been exceptionally good."

Jock Findlay, who heads the NHMRC licensing committee, says the approval process gave applicants two weeks to comment on draft licenses. "It's a healthy thing, because you are in communication with the applicant and working together to make sure it will work," says Findlay.

Meanwhile a collaborative project between Melbourne's Monash Institute of Medical Research and a Sydney group headed by Bernie Tuch of the University of New South Wales is also preparing license applications to create cloned embryos for stem cell lines.

After a late start, Australia may have two contestants in the therapeutic cloning race by the end of next year.

Simon Grose, Canberra, Australia

\section{Safer stem cells}

Stem cells and controversy often seem inextricably linked. Recent advances in generating so-called 'induced pluripotent stem cells' (iPS cells) have helped address some critics' concerns, as these cells are not derived from embryonic tissue. However, many experts still fear that the viruses used to transform regular cells into iPS cells could turn rogue and cause uncontrolled changes, such as cancer.

Now scientists have developed a new way to generate iPS cells that potentially avoids the viral hazards thought to plague these stem cell lines. Matthias Stadtfeld of the Harvard Stem Cell Institute in Boston and his teammates used a heavily modified version of the common cold virus (the adenovirus) to completely override the genetic program of liver and connective tissue cells taken from adult mice, causing those mature cells to revert to an embryonic state (Science, doi:10.1126/science.1162494; 2008).

Their technique involves trimming the adenovirus down to just the piece needed to transfer the key transcription factors required for genetic reprogramming to the mouse cell, creating a viral vector that serves only as a shuttling tool. This approach renders the virus unable to integrate into the mouse cell genome or replicate on its own. The viral vectors are even lost from the cell over time. Other stem cell lines rely on viruses such as retroviruses that integrate permanently into the host cell's genome-an undesirable effect.

Stadtfeld notes that this method of creating iPS cells works better in liver cells than in fibroblasts, which generate connective tissue and are commonly used by stem cell researchers. One reason for this may be that adenoviruses infect liver cells more easily.

At this point, the method is still a research tool. Stadtfeld says, "In principle, there is no reason why we can't use this technology to generate this type of stem cell in human cells, and this is likely to be done in the next six to twelve months." In the short term, Stadtfeld hopes to use these cells for drug screening and, in the long term, to treat genetic diseases, such as sickle cell anemia.

The adenovirus approach represents one of a growing number of attempts to make safer iPS cells. A paper published in October suggested that exposing skin cells to a chemical—valproic acidcould reduce the number of genes that the cells need to receive to revert to iPS cells (Nat. Biotechnol. doi:10.1038/nbt.1502; 2008).

Genevive Bjorn, Maui, Hawaii 